| GOSOS | Gaziosmanpaşa Üniversitesi Sosyal Bilimler Araştırmaları Dergisi Gaziosmanpasa University Social Sciences Researches Journal

(Kış 2016) 11/2: 107-124 / (Winter 2016) 11/2: 107-124

Doi Number :http://dx.doi.org/10.19129/sbad.300

\title{
OSMANLI DEVLETI'NIIN I. DÜNYA HARBİ ESNASINDA YAŞADIĞI KÖMÜR SIKINTISI VE ALINAN TEDBİRLER
}

İsa TAK $^{*}$

\begin{abstract}
Bu çalışma ile Osmanlı Devleti'nin I. Dünya Harbi esnasında kömür ve kömür üretimi konusunda yaşadığı sıkıntılar ve bu sıkıntıların giderilebilmesi için alınan tedbirler ve sonuçları ortaya konulacaktır.

Osmanlı Devleti'nin sahip olduğu kömür yataklarının başında Ereğli Havzası'ndaki Ereğli Kömür Madenleri gelmekteydi. Bu madenden yapılan üretim devletin ihtiyaç duyduğu kömürü tam olmasa da yaklaşık olarak karşılamaktaydı. Ereğli Havzası'nda kömür üretimi 1911 senesinde 904.000, 1912'de 810.000, 1913'te 826.000, 1914 senesinde $674.000,1915$ 'te $420.000,1916$ 'da $208.000,1917^{\prime}$ de 158.000 ve 1918 'de 186.000 ton olarak gerçekleşmiştir. Bu dönemde iç tüketim en yüksek seviyesine Öz 1.069.000 ton ile 1911 senesinde çıkmıştır. I. Dünya Harbi esnasında üretim normal olarak devam ettirilemediği için hızla azalmıştır. Bu nedenle demiryollarında çalışan trenlerde odun yakılmağa başlandığı gibi Şirket-i Hayriye vapurlarında zeytin posası dahi yakılmak mecburiyetinde kalınmışıı. Savaş sırasında ortaya çıkan kömür sıkıntısından dolayı önce idari olarak düzenlemeye gidilmiş ve Harp Kömür Merkezi kurularak kömür işleri bu merkeze verilmiş, ayrıca yeni kömür madenleri işletmeye açılmış ve hatta Almanya'dan kömür satın alınmıştır. Yapılan düzenlemeler ve alınan tedbirlere rağmen harp süresince kömür sıkıntısı devam etmiştir.
\end{abstract}

Anahtar Kelimeler: Osmanlı, Kömür, Savaş.

\section{THE COAL SHORTAGE IN THE OTTOMAN EMPIRE DURING THE FIRST WORLD WAR AND THE MEASURES TAKEN}

In this study, the difficulties that the Ottoman Empire faced in coal production during the First World War and the measures taken to overcome these difficulties and the results will be presented.

Abstract Ereğli Coal Mines in Ereğli coal basin were the major coal mines in the Ottoman Empire. The coal production from this mine couldn't meet the need of the state fully but it was almost enough. The coal production in Ereğli basin was recorded to be 904.000 tons in $1911,810.00$ tons in $1912,826.000$ tons in $1913,674.000$ tons in 1914, 420.000 tons in 1915, 208.000 tons in 1916, 158.000 tons in 1917 and 186.000 tons in 1918. During this period, domestic consumption increased to the highest level with 1.069 million tons in 1911. Production has declined rapidly during

\footnotetext{
*Yrd.Doç.Dr., Gaziosmanpaşa Ü niversitesi Eğitim Fakültesi, Sosyal Bilimler ve Türkçe Bölümü, e-posta: isa.tak@gop.edu.tr
} 
World War I, because it couldn't continue normally. For this reason, it was started to burn wood in the trains. Even the ferries of Şirket-i Hayriye were obliged to burn olive pomace. Some administrative arrangements were made due to the coal shortage during the war and War Coal Centre was founded and it took charge of all the affairs related to coal. Also, new coal mines were opened and even coal was purchased from Germany. In spite of the regulations and measures taken, the coal shortage continued during the war.

Key Words: The Ottomans, Coal, War.

\section{GİRIŞ}

20. yüzyılın ilk çeyreğinde, devletler için üretim ve nakliye faaliyetlerinin yerine getirilmesinde en önemli enerji kaynağı kömürdü. Dolayısıyla bu enerji kaynağına sahip olmak son derece önemliydi. Üstelik harp hali söz konusu ise bu husus daha da önem kazanmaktaydı. Bir taraftan üretim tesislerinin faaliyetlerini sürdürmesi diğer taraftan bu üretim ile askeri personelin hızlı bir şekilde taşınması gerekliydi. Devleti'nin sahip olduğu kömür üretim yerleri içerisinde Ereğli Kömür Havzası önemli bir konumda bulunuyordu.

Kömürler Osmanlı ülkesindeki endüstriyel buhar makineleri, demiryolları, demir-çelik üreticileri, evler, elektrik üretim şirketleri, havagazı şirketleri ve buharlı gemilerde kullanılıyordu(Kara,2009:3, 2010:XXXI, 2013:224). Ereğli Havzası kömürleri ise başta donanma olmak üzere Şirket-i Hayriye, Gazhane, Terkos Su Şirketi, Elektrik Şirketi, Seyr-i Sefain İdaresi(Genç,2007:2), İzmit Çuha Fabrikası, Hereke Fabrika-i Hümayunu, Karamürsel Mensucat Fabrikası, İzmit Arslan Çimento Fabrikası, Eskihisar Çimento Fabrikası(Dölen,2014:670-684) gibi ülkedeki farklı şehirlerde bulunan tesislerin(Öğreten,2006:154) ihtiyaçlarını karşılamaktaydı.

\section{I.a. Harpten önce ve harp esnasında Osmanlı Devleti'nde kömür durumu}

Osmanlı Devleti'nin kullandığı kömürlerin çoğu Ereğli Kömür Madenlerinden karşılanmakla beraber, bir kısmı İngiltere'den satın alınıyordu. Bunun sebebi Ereğli Havzası'ndaki üretimin yetersizliği değildi. Bir taraftan dışarıdan kömür ithal edilirken diğer taraftan Ereğli kömürü de dişarıya ihraç ediliyordu. 1908 senesinde dişarıdan ithal edilen 203.000 ton kömüre karşılık 329.000 ton kömür ihraç edilmiştir. Ancak bundan sonra ithalat ihracattan fazla olmuştur. İthalatın ihracata göre fazlalığ 1 ortalama 150.000 ton civarında gerçekleşmiştir(Eldem,1994:50,).

Ereğli Havzası'nda 1911 senesinde 904.000 ton, 1912'de 810.000 ton ve 1913 'te ise 826.000 ton kömür üretilmiştir. Bu dönemde iç tüketim en yüksek seviyesine 1.069 .000 ton ile 1911 senesinde çıkmıştır(Eldem,1994:58). Üretim normal olarak devam ettirilmiş olsaydı, alınan tasarruf tedbirleri sonucunda, Ereğli Kömür Madenleri devletin kömür 


\section{Osmanlı Devleti'nin I. Dünya Harbi Esnasında Yaşadığı Kömür Sıkıntısı ve Alınan Tedbirler}

ihtiyacını rahatlıkla karşılayabilirdi. Ancak bu yapılamadığı için havza üretimi hızla azalmıştır. 1914 senesinde 674.000 ton, 1915 'te 420.000 ton, 1916'da 208.000 ton, 1917 de 158.000 ton ve 1918 'de 186.000 ton kömür üretilmiştir (Çatma,1998:112). Üretimin düşmesi sonucu kömür sıkıntısı kendini hissettirmeye başlamıştır. Bu nedenle demiryollarında çalışan trenlerde odun yakılmağa başlanmıştır. Bu yüzden demiryollarına odun ve kömür gönderilmesi amacıyla Karargâh-1 Umûmî bünyesindeki Kömür Şubesine çok sayıda başvuru yapılmıştır(ATASE, BDH, Kls;903, Dos;102/1073, Fih;1-159). Ayrıca Şirket-i Hayriye vapurlarında zeytin posası dahi yakılmak mecburiyetinde kalınmıştır(Şirket-i Hayriye İdaresi,1337:26). Üretimin yetersiz oluşu sebebiyle ortaya çıkan sıkıntı, kömürün çok yüksek fiyatlardan satılmasına yol açmıştır(Şirket-i Hayriye İdaresi,1337:32-40).

Savaş sırasında ortaya çıkan kömür sıkıntısından dolayı Osmanlı Devleti yeni kömür madenlerini işletmeye açmış ve hatta Almanya'dan kömür satın almıştır(BOA, DH-İ. UM., E-26/57). Buna rağmen harp süresince kömür sıkıntısı devam etmiştir.

\section{I.B. Kömür Sıkıntısının Sebepleri}

1- Savaş sırasında Osmanlı Devleti'nin kömür sıkıntısı çekmesinin sebeplerinden biri Ereğli Havzası'na yapılan Rus saldırılarıdır. Yapılan bu Rus saldırıları kömür üretimini durduramamış olmakla birlikte, özellikle sahile yakın bölgelerde etkili olmuştur. Arka arkaya yapılan saldırılar her şeyden önce rahat ve düzenli bir çalışma imkânını ortadan kaldırmıştır. Saldırılar sonucunda birçok maden ocağında hasarlar meydana gelmiştir. Gerek bu hasarlar ve gerekse bunların tamiri için çalıştırılan kişiler, üretim faaliyeti yerine tamir işleriyle uğraşmak mecburiyetinde kalmışlardır. Dolayısıyla bu hususlar üretimin azalmasında etkili olmuştur. (Ereğli Kömür Havzası ve buradan yapılan kömür nakliyatına yönelik Rus saldırıları ve alınan tedbirler hakkında geniş bilgi için bk.Tak, 2001:120-123)

2- Ereğli Madenleri ihracatının artmasında önemli rolü olan teknik personelin önemli bir bölümü Fransız idi. Savaşın başlamasıyla çok sayıda Fransız kendi memleketlerine gitmiştir(BOA, DH- EUM. EMN, 90/58). Bu durum ise, havzadaki üretimin düşmesinde oldukça etkili olmuştur.

3- Osmanlı Devleti'nin harbe girmesiyle havzada çalışan ve yaptığı işi iyi bilen işçilerin silâh altına alınmasıdır. Özellikle Çanakkale Cephesi'nin açılması ve ardından harbin bütün şiddetiyle uzun süre devam etmesi askere olan ihtiyacı artırmış ve bu işçilerin gidişi havzada ciddi bir işgücü bunalımı ortaya çıkarmıştır. Bu işçilerin yerine çocuklar, yaşlılar, çürüğe ayrılanlar ile daha önce madende hiç çalışmamış olanlar istihdam edilmiştir. Bu işgücü kaybı üretimi düşürmüştür (Çatma,1998:111-112).

4- Osmanlı Devleti'nin Ereğli Havzası'nda üretilen kömürleri güvenli ve düzenli bir şekilde taşıyamamasıdır. Ereğli Havzası'ndan yapılan nakliyatın düşman

| Gaziosmanpaşa Üniversitesi Sosyal Bilimler Araştırmaları Dergisi 
tarafından sürekli olarak tehdit edildiği, hatta engellendiği 1877-78 Osmanl1-Rus Harbi sırasında çok açık bir şekilde görülmüştü. Bu sebeple, Ereğli Havzası'nda üretilen kömürlerin düşman baskısından uzak ve güvenli bir şekilde nakli için Ereğli Havzası'na demiryolu bağlantısının kurulması gerekliydi. Osmanlı Hükümeti, Anadolu demiryollarının yapımı plânı içerisine Adapazarı, Ereğli Hattı'nı da koymuştu(Eldem,1994:99). Ancak Zonguldak'a liman yapımı için Osmanlı vatandaşı Yanko Bey'e verilen bir imtiyazın nasıl Fransız sermayesi ile kurulan Ereğli Şirketi'ne dönüştüğü ve devlet için çok önemli bir problem haline geldiği(geniş bilgi için bk.Tak,2001:53-95) tecrübe ile sabit olduğundan söz konusu hattın yapımından vazgeçilmiştir(BOA, İ. Hus, 1325 N/82).

Harp esnasında Rus saldırıları sonucunda kömür nakliyatında sıkıntıların ortaya çıkmasıyla birlikte, Ereğli Havzası'na demiryolu yapılması tekrar gündeme gelmiştir. Hâlbuki Osmanlı Devleti'nin I. Dünya Harbi öncesinde bu hattı mutlaka bitirmiş olması gerekirdi. Hiç olmazsa, bu hattın yapımı için gerekli olan malzemeler Osmanlı Devleti sınırları içerisine getirilmeliydi. Çünkü 1916 Ocak ayında Berlin-İstanbul Hattı'nın açılmasına kadar bu malzemelerin getirilmesi imkânı yoktu. Bu tarihten sonra ise, askeri nakliyatın yoğunluğu sebebiyle, bu uzunluktaki bir hattın malzemelerinin getirilmesi mümkün değildi(BOA, DH-İ. UM., E-26/57). Bu sebeple Osmanlı Devleti havza kömürlerini deniz yoluyla taşımak mecburiyetinde kalmıştır. Dolayısıyla Rus donanmasının kömür nakline yönelik saldırıları sonucunda çok sayıda nakil vasıtaları ve özellikle yüksek tonajlı gemiler kaybedilmiştir. Bu kayıpların sonucunda ise nakliye konusunda ciddi sıkıntılar yaşanmıştır. Bu sıkıntıların giderilmesi amacıyla bir ara kara yolu ile nakliye denenmiş 1915 senesi Eylül, Ekim ve Kasımında üç ay süreyle Ereğli- Adapazarı hattından karadan kömür nakledilmiş olmakla birlikte sonradan bundan vazgeçilmiştir(BOA, DH-İ. UM., E- 26/57).

5- Osmanlı Devleti'nin savaştığı devletlerin vatandaşı olup, Ereğli Havzası'nda çalışmakta olan madencilerin işi yavaşlatmaları hususu da göz ardı edilmemelidir.

6- Osmanlı Devleti'nin havzadan aldığı kömür bedellerini peşin ödeyememesi havza üreticilerinin amele istihdamı konusunda sıkıntı yaşamalarına ve bu yüzden üretimi düşürmelerine sebep olmuştur(Genç,2007:225).

\section{I.C. Kömür Sıkıntısını Gidermek İçin Alınan Tedbirler}

2 Ağustos 1914 tarihinde Almanya ile ittifak anlaşmasının imzalanmasının ardından Osmanlı Hükümeti, Kozlu ve Zonguldak'ta bulunan yıkanmış kömürlere "Tekâlif-i Harbiye Usûlüyle" el konulması kararını almıştır. Hükümetin aldığı bu karar, Dâhiliye Nezareti tarafından 15 N 1332 (8 Ağustos 1914) tarihli şifre ile Bolu Mutasarrıflığına tebliğ edilmiştir(BOA, DH, ŞFR., 43/ 194). Bu karar gereğince el konulan kömürlerin yetersiz oluşu sebebiyle hükümet Ereğli Havzası'ndan dışarıya 


\section{Osmanlı Devleti'nin I. Dünya Harbi Esnasında Yaşadığı Kömür Sıkıntısı ve Alınan Tedbirler}

kömür ihracı ve satışını yasaklamıştır(BOA, MV, 213/72). Dâhiliye Nezareti, 13 Z 1332 (2 Kasım 1914) tarihli şifre ile Bolu Mutasarrıflığından Ereğli ve Zonguldak Kömür Madenleri'nde her türlü vasitaya müracaat ederek üretimin en üst düzeye çıkartılmasını istedi(BOA, DH. ŞFR., 46/145). Bir gün sonra gönderilen ikinci bir şifre ile de; "kömür ihracâtının başka suretle olmadığı takdirde icbâren teminine çalışılması"( BOA, DH. ŞFR., 46/159) istenmiştir.

Bir taraftan Ereğli Havzası'ndan çıkarılan kömürün üretimini artırmak için çaba gösterilirken diğer taraftan bu kömürlerin devlet adına satın alınması, nakledilmesi ve tüketilmesi işleri Harbiye Nezaretine devredilmiştir. Böylece, harbin sonlarına kadar kömür işleri Harbiye Nezareti tarafından yürütülmüştür. Harbiye Nezareti tarafından 7 Kasım 1914 tarihinde "Karargâh-1 Umûmi Üçüncü Şimendifer Şubesi"ne bağl1 "İskele ve Limanlar Kumandanlığı" bünyesinde bir "Kömür Şubesi" oluşturularak idaresi Bahriye Nezaretine verilmiştir (BOA, DH-İ. UM,E-26/57; BOA, BEO, 244149; Şirket-i Hayriye İdaresi,1337:31).

\section{Kömür Şubesinin Çalışmaları}

Ereğli Kömür Havzası'ndan çıkarılan kömürlerin hükümetin hesabına satın alınması, havzadan nakli, nerelere ve ne miktarlarda verileceği hususları bu şubenin idaresine birakılmıştır. Bu amaçla kömür şubesinin emrine bin-iki bin ton kömür taşıyabilen 22 vapur verilmiştir(Besbelli,1976:129). Adı geçen şube tarafından kömür işlerine nezaret etmesi için Ereğli Havzası'na bir Alman subayı gönderilmiştir(BOA, DH-İ. UM., 89-2/1-26). Kömür Şubesi tarafından; donanma, demiryolları, Seyr ü Sefâîn İdaresi, İstanbul elektrik santrali, askerî fabrikalar ve özel idarelere gerekli olan kömür miktarı da tespit edilmiştir(Besbelli,1976:129)./

Kömür işleri, ilgili şube tarafından bu şekilde yürütülmekle beraber, Rus saldırılarının artması sebebiyle, bir takım aksaklıklar da ortaya çıkmağa başlamıştır. Özellikle, kömür taşıyacak gemilerin gönderilme zamanı ile bunların yükleme yapacakları yerlerin tespiti İstanbul'da yapılıyordu. Bu durum ise hava muhalefeti yüzünden gemilerin zaman kaybetmelerine veya yükleme yapacakları yerlerde beklemelerine yol açmıştır. Dolayısıyla Rus saldırıları sonucunda nakliye gemilerinin bir bölümü kaybedilmiştir. Zonguldak Kaymakamlığı 1 Mayıs 1331 (14 Mayıs 1915) tarihli bir tezkire ile Bolu Mutasarrıflığına mevcut uygulamanın yanlış olduğunu, kömür alınacak iskelelerin Alman subayının denetimi altında bulunan Zonguldak tarafından tespit edilmesi gerektiğini bildirmiştir(BOA, DH-İ. UM., 89-2/1-26).

Kayıpların artması Kömür Şubesinde gemi ihtiyacını ortaya çıkarmıştır. Zaten bu şubeye tahsis edilmiş olan gemilerin tamamı hükümetin malı da değildi. Bu yüzden gemi sahipleri ve gemi personeli için güvence verilmek suretiyle nakliye vasıtası sıkıntısı giderilmeye çalışılmıştır. Başkumandanlık Vekâletinin hazırladığı 4

| Gaziosmanpaşa Üniversitesi Sosyal Bilimler Araştırmaları Dergisi 


\section{İsa TAK}

Mayıs 1331 (17 Mayıs 1915) tarihli kanun teklifi, 19 B. 1333 (2 Haziran 1915) tarihinde "Karadeniz'den Dersaâdet'e Maden Kömürü Nakleden Sefần ve Mürettebatı Hakkında Kanun" olarak onaylanıp yürürlüğe konulmuştur. Toplam sekiz maddeden oluşan bu kanun ile, zarar ve ziyanın hükümet tarafından tazmini öngörülmüştür. Ancak, gemi sahipleri ve kaptanlarının hataları sebebiyle ortaya çıacak zarar ve ziyan tazmin edilmeyecektir. İster düşman saldırısı sonucunda, isterse gemi sahipleri ve kaptanlarının hataları ile sakatlanan gemi personeline, maluliyet maaşı tahsis edilmesi, ayrıca söz konusu personelin hayatını kaybetmesi durumunda ailesine maaş bağlanması hükme bağlanmıştır. Bu kanun harp süresince yürürlükte kalacaktı(BOA, İ. Meclis-i Mahsûs,1333 B/18; Takvîm-i Vekayî, 2264,1331: 1).

Ereğli Havzası'ndan yapılan kömür nakliyatını Rusların sürekli olarak taciz etmeleri ve bunun sonucunda birçok nakliye gemisi kaybedilmesi üzerine, nakliyatın olabildiğince geceleri yapılmasına çalışılmıştır(Besbelli,1976:138). Kömür Şubesinin kömür işlerini devralmasından itibaren gerek bu şube emrindeki gerekse diğer kuruluşlara ait gemilerin kömür almak üzere Karadeniz'e açılmaları rastgele veya kendi insiyatifleri doğrultusunda olmamıştır. Bu konuda Kömür Şubesinin izni olmaksızın hiçbir gemi Karadeniz'e bırakılmamıştır. Ayrıca söz konusu şube tarafından kömür nakliyatında kullanılmak üzere ticaret gemilerinin çoğuna da el konulmuştur (Şirket-i Hayriye İdaresi,1337:31).

Alınan tedbirler ve yapılan çalışmalara rağmen istenilen cins ve miktarda kömür üretiminin gerçekleşmemesi ve nakliyatın da bir düzene konulamaması sebebiyle Umum İskele ve Limanlar Kumandanlığına bağlı bulunan Kömür Şubesi, Karargâh-1 Umûmi Üçüncü Şubesi emrine verilmiş ve ismi Harp Kömür Merkezine çevrilmiştir(BOA, DH-İ. UM., E-26/57; ATASE, BDH., Kls., 904, Dos., 1078, Fih., 1-46; Besbelli,1976:129). Bu tarihten itibaren kömür işleri tamamen Harp Kömür Merkezine bırakılmış(Yorulmaz,1998:293) ve bu merkezin başına bir Alman yüzbaşı tayin edilmiştir. Kömür sıkıntısı ve bu konuda alınacak tedbirler konusunda Harp Kömür Merkezince yapılan toplantıya Karargâh-1 Umûmi Erkân-1 Harbiye İkinci Başkanı olan Alman generali başkanlık etmiştir. (Geniş bilgi için bk. BOA, DH-İ UM., E-26/57).

\section{Harp Kömür Merkezi ve Çalışmaları}

Kömür işlerinin Harp Kömür Merkezine devredilmesinden sonra bu merkez tarafından yapılan ilk çalışma nakliye konusunda olmuştur. Rus saldırıları ile Ereğli Havzası'ndan deniz yoluyla yapılan kömür nakliyatı iyice azalmış hatta bazen nakliyat kesilmek mecburiyetinde kalınmıştır. Bu durum ise, kömür sıkıntısının iyice artmasına yol açtığından kara yoluyla kömür taşınması için çalışmalar başlatılmıştır. Bu çalışmalar neticesinde bir "Menzil Hattı" kurulmuştur. 


\section{Osmanlı Devleti'nin I. Dünya Harbi Esnasında Yaşadığı Kömür Sıkıntısı ve Alınan Tedbirler}

\section{Kara Yoluyla Yapılan Kömür Nakliyatı (Ereğli-Adapazarı Menzil Hattı)}

Başkumandanlık Vekâletinin İzmit ve Bolu Mutasarrıflıklarına gönderdiği 17 Ş 1333 (30 Haziran 1915) tarihli şifresinde; "Karadeniz Ereğlisi'nden Akçaşehir'e kadar denizden, Akçaşehir'den Düzce-Hendek üzerinden Adapazarı'na kadar karadan kömür celb edilecek ve bunun için bir Menzil Hattı tesîs olunacaktır. İşi tanzîm etmek üzere, EreğliAdapazarı Menzil Hattı için bir hat kumandanı gönderilecektir. Gerek kumandan ve gerek hat üzerinde bulunacak zâbitâna vazîfelerini yapmaları için her türlü yardımın yapılması hususunda mahalli memurlara gerekli emirlerin verilmesi" istenmiştir(BOA, DH.ŞFR., 54/241).

Başkumandanlık Vekâletinin emirleri doğrultusunda gerekli hazırlıklar Menzil Hattı Kumandanı nezaretinde yapılmağa başlanmıştır. Bu sırada Bolu Mutasarrıflı̆̆ bir suretini Harbiye Nezaretine diğer suretini de Dâhiliye Nezaretine gönderdiği 14 Temmuz 1331 (28 Temmuz 1915) tarihli bir yazı ile bir takım uyarılarda bulunmuştur. Bu uyarılar özetle şöyledir: "Kömür nakliyâtı için karadan Ereğli-Adapazarı arasındaki menzil hattı güvenli değildir. Akçaşehir açık ve korumasız olduğundan buraya iskele yapılması uygun olmayıp düşman saldırılarına açıktır. Yazın bile kötü havalarda buraya yanaşmak imkânsız iken kışın şiddetli rüzgârlar sebebiyle hiç kullanılamayacaktır. Bu sebeple boşa masraf yapılmamalıdır. Ayrıca Akçaşehir'deki depo şehrin meydanında olduğundan ve açıkça Rus gemilerine hedef teşkil ettiğinden saldırıya uğraması ihtimal dâhilinde olup bu yüzden ahalinin ve binanın tahribi kaçınılmaz olacaktır. En güvenilir yol olup, kömürün de merkezi olan Zonguldak'tan Devrek'e oradan Düzce ve Adapazarn'na uzanacak bir şekilde nakli, belki bir-iki gün gecikmeye sebep olacak ancak, tamamen tehlikeden uzak olacaktır. Bu yolun sadece DevrekZonguldak arasında yapım çalışmalarn sürüyor. Ĕ̆gr amele taburları buraya gönderilir ise kısa sürede hazır hale gelir. Bu yapılmaz ise, Akşehir'deki depo emin bir yere alınmalıdır"( BOA, DH-İ. UM., 89-2/1-26).

Bolu Mutasarrıflığının yaptığı uyarılar dikkate alınmamış ve verilen emirler doğrultusunda hazırlıkların tamamlanmasından sonra 1915 senesi Eylül, Ekim ve Kasımında üç ay süreyle karadan kömür nakledilmiştir(BOA, DH-İ. UM., E-26/57). Karadan kömür nakli şu şekilde gerçekleştirilmiştir. Ereğli'den kömür yüklü olarak yola çıkan kayıklar yedi saatte Akçaşehir'e gelirler ve kömürleri buraya boşaltırlardı. Denizden yapılan bu nakliyata bir yüzbaşı nezaret ederdi. Katarların geriye dönüşlerine kadar getirilen kömürler Akçaşehir'de yüzbaşı rütbesindeki kömür anbar memuru nezaretinde depo edilirdi. Yüklenen katarlar ise, Düzce-Hendek üzerinden Adapazarı'na nakledilirdi. Katarlara da yüzbaşı rütbesinde komutanlar nezaret ederdi. Bir katar elli arabadan oluşup 25 ton kömür naklederdi(ATASE, BDH., Kls., 2631, Dos., 12, Fih., 4-1). Kömür yüklü katarların Adapazarı'na gidip yükünü boşalttıktan sonra Akçaşehir'e dönmesi dokuz gün sürmekteydi. Bu dönemde toplam 3.600 manda arabası kullanılmıs olmasına rağmen hayvanların telef olması, arabaların kırılması ve başka sıkıntılar neticesinde ancak günde 200 ton kömür nakli yapılabilmiştir. Diğer

| Gaziosmanpaşa Üniversitesi Sosyal Bilimler Araştırmaları Dergisi 
taraftan denizden kayıklarla yapılan nakliyatın sürekli olarak Rus deniz kuvvetleri tarafından rahatsız edilmesi ve bunun sonucunda bir takım zarar ve ziyanın ortaya çıkması sebebiyle mecburi olarak kara nakliyatından vazgeçilmiştir(BOA, DH.İ. UM., E-26/57).

\section{Linyit kömür ocaklarının açılması ve işletilmesi}

Deniz yoluyla kömür nakliyatını korumak için daha önce bahsedilen tedbirler alınmış olmasına rağmen, bu tedbirlerin yetersiz kalması yüzünden Rus donanması etkili olmaya devam etmiştir. Dolayısıyla ihtiyacı karşılayabilecek şekilde kömür nakledilmediği için kömür sıkıntısı iyice artmıştır. Bunun üzerine Harp Kömür Merkezi tarafından, daha önce Kömür Şubesince 1915 Mayıs ayından itibaren düşünülmüş olan, linyit ocakları 1915 yılı sonlarına doğru açtırılmıştır(BOA, DH.İ. UM., E-26/57). Açllan bu ocakların idaresi Harp Kömür Merkezinin nezaretine bırakılmıştır. Söz konusu linyit madenlerinde her türlü kontrol Harp Kömür Merkezine ait olduğu halde Ereğli Kömür Madenleri idarî olarak bu merkezin denetimine bırakılmamıştır(ATASE, BDH., Kls., 904, Dos., 1078, Fih., F-46/47). Harp Kömür Merkezi bu madenlerin işletme işini, kendi nezareti altında, kömürlerin tüketildiği kuruluşlara havale etmiştir(BOA, DH.İ. UM., E-26/57).

Kömür sıkıntısı ile ilgili olarak Harp Kömür Merkezinde yapılan 12 RA 1335 (6 Ocak 1917) tarihli toplantı zabıtlarında linyit madenleri hakkında aydınlatıcı bilgiler yer almaktadır. Burada yer alan bilgilere göre; linyit madenlerinin yerleri, kimler tarafından işletilmekte olduğu ve çıkarılan kömür miktarı şöyledir:

Soma, Söke ve Nazilli ocaklarının ihracatı Batı Anadolu'nun bilhassa İzmirKasaba ve İzmir-Aydın şimendiferiyle, Anadolu şimendiferlerinin ihtiyaçları için kullanilmaktadir.

Bekleme, Levazım-1 Umumiye tarafından işletilmekte olup, aylık 8.000 tonu bulan ihracatı Levazımat-1 Umumiye fabrikaları vs. emrindedir.

Ayazma, Esliha Müfettişliği tarafından işletilmekte olup aylık 1.800 ton olan ihracat, bu müfettişlik ihtiyaçları için kullanılır.

Kistanbul, Şark Demiryolları tarafından işletilmekte olup aylık 1.800 tonu bulan ihracatın büyük çoğunluğu İaşe-i Umumiye Merkezi, kalan 400 ton civarındaki kömür ise Şark Demiryolları fabrikalarında kullanılır.

Tekfur Dağı, Bahriye Nezareti tarafından işletilmektedir. 2.400 ton olan aylık ihracatın önemsiz bir kısmı Harp Kömür Merkezinde, kalanı ise Bahriye Nezaretine bağlı fabrikalarda kullanılır.

Şevketiye, Karargâh-1 Umûmî tarafından işletilip, aylık 700 ton kömür 


\section{Osmanlı Devleti'nin I. Dünya Harbi Esnasında Yaşadığı Kömür Sıkıntısı ve Alınan Tedbirler}

çıkartılmaktadır. Çanakkale ihtiyacına tahsis edilmiş olup ihtiyacı karşılayamamaktadır.

Bozüyük, Anadolu Şimendiferleri tarafından işletilmektedir. İhraç olunan aylık 600 ton kömür Anadolu Şimendiferleri atölyelerinde kullanılmaktadır(BOA, DH.İ. UM., E-26/57).

Linyit ocaklarından aylık, yaklaşık 20.000 ton kömür çıkarılmış olmasına rağmen, yine de kömür sıkıntısı giderilememiştir. Bunun en önemli sebebi ise önemli nakliye gemilerinin kaybedilmesiyle nakliyatın hayli azalmasıdır(Besbelli,1976:318). Ancak her şeye rağmen ihtiyaç duyulan kömürlerin önemli bir kısmı bu ocaklardan temin edilmiştir.

Maadin Nizamnâmesi'nin 26. maddesi gereğince kömür ve linyit madenleri arama ruhsatnâmelerine sahip olanların ihracatı 2.000 ton ile sinırlandırılmıştı. Ancak, bu dönemde aşırı derecede kömür sıkıntısı ortaya çıkmıştır. Bunun üzerine 12 R 1334 (16 Şubat 1916) tarihinde yapılan Meclis-i Vükelâ toplantısında bu ruhsatnâmelere sahip olanların 2.000 tondan fazla kömür çıkarmalarına izin verilmesi için gerekli düzenlemenin yapılması kararlaştırılmıştır (BOA, MV., 200/60).

\section{Almanya'dan Kömür Getirilmesi}

Kömür sıkıntısının en üst düzeye çıktığı 1915 senesi sonlarında açılmağa başlanan linyit ocaklarından da ihtiyacı karşılayacak miktarlarda üretim yapılamamıştır. Bu sebeple, kömür sıkıntısını gidermek için Almanya'dan kömür ithaline karar verilmiştir. Bu kararda, 17 Ocak 1916 tarihinde ilk Berlin-İstanbul treninin gelişiyle demiryolu bağlantısının kurulması etkili olmuştur(Besbelli,1976:318). Osmanlı Devleti'nin yeterli ihtiyat kömürünün bulunmayışından(BOA, DH.İ. UM., E26/57), Harp Kömür Merkezinin isteği üzerine Başkomutanlık Vekâleti 1916 Şubatı başında Almanya'dan kömür istemiştir(Besbelli,1976:318). Almanya bu isteğe, Macaristan'daki ağır kış şartları dolayısıyla(BOA, DH.İ. UM., E-26/57), şubat sonundan itibaren günde 400 ton kömür gönderileceği cevabını vermiştir. Böylece 1916 yılı Mart ayından itibaren Almanya'dan kömür ithal edilmeye başlanmıştır(Besbelli,1976:318).

1917 senesi Martı sonuna kadar Almanya'dan ayda ortalama 7.000 ton kömür ithal edilmiştir. Almanya, gönderdiği kömürün tonunu, nakliye ücreti hariç 6 liradan hükümete vermiştir(BOA, DH.İ. UM., E-26/57). Harp Kömür Merkezi tarafından yapılan kömür tahdidat plânında, Almanya'dan ithal edilecek kömürün miktarı aylık 13.360 ton olarak yapılmış olmasına rağmen, bu miktar hiçbir zaman aylık 10.000 tonu geçmemiştir. Zaten bir süre sonra Alman kömürü ithalinden vazgeçilmiştir(BOA, DH.İ. UM., E-26/57; BOA, DH.İ. UM., E-50/4-23).

| Gaziosmanpaşa Üniversitesi Sosyal Bilimler Araştırmaları Dergisi 


\section{Zonguldak İle Adapazarı Arasında Demiryolu Yapılması Girişimi}

Harbin başlangıcından 1915 senesi Mart ayı sonuna kadar Ereğli Havzası'ndan İstanbul'a aylık 46.000 ton kömür taşınmıştı. Bu tarihten sonra şiddetli Rus saldırıları sonucunda önemli ölçüde nakliye vasıtası kaybedilmiştir. Saldırıların devam etmesi ve vasıta sıkıntısı sebebiyle büyük fedakârlıklar sonucunda Seyr ü Sefâîn (Levazımat-1 Umumiye) Bahriye Nezareti, Harp Kömür Merkezi ve bazı hususî tüccar tarafından yelken, mavna ve küçük gemiler ile nakliyata devam edilmiştir. Lâkin 1916 senesi başından Ağustos ayına kadar geçen sürede toplam 22.000 ton kömür nakledilebilmiştir. Bu yüzden Harp Kömür Merkezinin 12.3.1335 (6 Ocak 1917) tarihli toplantısında Ereğli Havzası ile Adapazarı arasında demiryolu yapılması kararlaştırılmıştır(BOA, DH.İ. UM., E-26/57).

$\mathrm{Bu}$ karar üzerine Avusturya-Macaristan Hükümeti Murahhas-1 Askerîsi tarafından Zonguldak ile Adapazarı arasında dar bir hat yapılması teklif edilmiştir. Yapılan teklif içerisinde yapım masraflarına karşılık, Osmanlı Hükümeti'nden yapacakları hatlar ile bazı madenlerin imtiyazını talep etmişlerdir. Hükümet, söz konusu teklifi Harbiye Nezaretine bildirmiş ve görüş istemiştir. Harbiye Nezareti tarafından özetle; "İhtiyaç duyulan kömürün nakli konusunda önemli olan böyle bir teklifin dikkate değer olduğu ancak herhangi bir imtiyaz verilmemesi, yalnız hatların yapımı ve harpten sonra hükümetçe satın alınması şartı ile inşaata başlanmasının murahhaslara tebliği" cevap olarak bildirilmiştir. Harbiye Nezaretinin 28 CA 1335 (22 Mart 1917) tarihli bu cevab1 12 C 1335(4 Nisan 1917) tarihli Meclis-i Vükelâ toplantısında görüşülmüştür. Görüşme neticesinde, "Adı geçen hatların masrafları hükümet tarafindan ödenmek ve harptan sonra devlete ait olmak ve başka şart belirtilmemek üzere inşasına istekli oldukları taktirde ihâle olunabileceğinin Harbiye Nezâretine tebliği" kararlaştırılmıştır(BOA, MV., 207/76). Osmanlı Hükümetinin aldığı karar doğrultusundaki bu ihale şartı, AvusturyaMacaristan Hükümeti tarafından kabul edilmediğinden hattın yapımı gerçekleştirilememiştir.

\section{I.D.Zonguldak Harp Kömür Komisyonu İle Maadin-İ Askerî Komiserliğinin Kurulması ve Çalışmaları}

Rusya'nın savaştan çekilmesi sonucunda Ereğli Kömür Madenleri ve buradan yapılan kömür nakliyatına yönelik saldırılar sona ermiştir. Bunun üzerine, Ereğli Havzası'ndaki ihracatın artırılması ve bununla ilgili çalışmaları yürütmesi amacıyla Harbiye Nezaretinin 30 Kanun-1 Sânî 1334 (30 Ocak 1918) tarihli emri ile Harp Kömür Merkezine bağlı Zonguldak Harp Kömür Komisyonu teşkil edilmiştir (BOA, DH.İ. UM., E-50/4-23). Komisyonun başkanlığına Bahriye Nezaretinden Miralay Mustafa Bey (BOA, DH.İ. UM., E-50/4-15;Naim,1934:82) atanmıştır. Komisyon üyeliklerine ise, Zonguldak Kaymakamı, Ereğli Madeni Müdürü ve Başmühendisi 


\section{Osmanlı Devleti'nin I. Dünya Harbi Esnasında Yaşadığı Kömür Sıkıntısı ve Alınan Tedbirler}

(Sarıkoyuncu,1992:303) ile Harbiye Nezareti ve Karargâh-1 Umumî'den gönderilen temsilciler (BOA, DH.İ. UM., E-50/4-23) tayin edilmiştir.

Harp Kömür Şubesinin bağlı olduğu Karargâh-1 Umumî İkinci Şubesi tarafından madencilere, komisyona yardımcı olmaları ve kömür ihracatını artırmaları hususunda, tebligat yapılmıştır. Komisyon 15 Şubat 1334 (15 Şubat 1918) tarihinde görevine başlamıştır. Ancak komisyon, madenlerde ihracatın artırılmasındaki en önemli unsur olan amele meselesini halledememiştir. Ameleler düzenli bir şekilde madenlere sevk edilememiş ve firar olayları artmıştır. Ortaya çıkan amele sıkıntısı kömür ihracatının istenilen düzeye ulaşamamasına yol açmıştır. Zonguldak Harp Kömür Komisyonu tarafından muhtarlara ve jandarmalara gerekli uyarılar yapılmış, ancak bir sonuç alınamamıştır. Bunun üzerine komisyon tarafından bir sureti Harbiye Nezaretine diğer sureti Ticaret ve Ziraat Nezaretine çekilen telgrafta amele, madenci, muhtar ve jandarmaların görevlerini yapmadıkları, bunların cezalandırılması için Zonguldak'ta hususî bir divan-1 harp kurulması istenmiştir. Söz konusu telgrafın bir suretini 7 Mart 1334 (7 Mart 1918) tarihli tezkire ile Dâhiliye Nezaretine gönderen Harbiye Nezareti, amelenin düzenli bir şekilde sevki ve istihdamı için ilgililere gerekli emirlerin verilmesini talep etmiştir(BOA, DH.I. UM., 19-1/1-10). Dâhiliye Nezareti de Bolu Mutasarrıflığına gerekli uyarıyı yapmıştır(BOA, DH.İ. UM., 19-1/1-21).

Harbiye Nezareti tarafından divan-1 harp kurulmasına sıcak bakılmamıştır. Ancak amele işlerinin bir düzene konulması amacıyla Ereğli Havzası'nda amelenin sevki, istihdamı, ücretlerinin tespiti ve iskânı işlerini yürütmesi için, bir komiserlik kurulmasına karar verilmiştir. Böylece Harbiye Nezareti tarafından 19 Mart 1334 (19 Mart 1918) tarihinde "Maadin-i Askeri Komiserliği" teşkil edilmiştir(BOA, DH.İ. UM., E-50/4-23). Komiserlik görevi de Miralay Mustafa Beye verilmiştir(BOA, DH.İ. UM., E50/4-15). Kömür ihracının düzenlenmesi ve artırılması çalışmalarından Zonguldak Harp Kömür Komisyonu, ameleler ile ilgili işlerden ise Maadin-i Askeri Komiserliği mesul tutulmuştur(BOA, DH.İ. UM., E-50/4-24). Böylece Harp Kömür Merkezinin Ereğli Havzası'nın idaresindeki etkinliği artmıştır. Bu artış, amelenin toplanması, çeşitli madenlere dağıtılması, iskânı ve ücretlerinin tespiti konularında gerçekleşmiştir(BOA, DH.I. UM., E-50/4-23).

Zonguldak Harp Kömür Komisyonu ile Maadin-i Askeri Komiserliğinin havzada birlikte çalışma yaptıkları 1918 yılı Ağustos ayı haricinde, Mart ayında 17.283, Nisan'da 20.883, Mayıs'ta 24.771, Haziran'da 21.068 ve Temmuz ayında 17.241 ton kömür çıkartılmıştır(BOA, DH.İ. UM., E-50/4-15). Görüldüğü gibi, Ereğli Kömür Madenlerinde ihracatın artırılması düşünülürken azalma meydana gelmiştir. $\mathrm{Bu}$ sebeple havzadaki yetkililere ihracatın artırılması için gerekli tedbirlerin alınması hususunda birçok uyarılar yapılmıştır. Bunun üzerine Zonguldak Kaymakamlığı tarafından konu ile ilgili bir rapor hazırlanmış ve 15 Ağustos 1334 (15 Ağustos 1918) tarihinde Bolu Mutasarrıflığına gönderilmiştir. Söz konusu raporda; Ereğli Kömür

| Gaziosmanpaşa Üniversitesi Sosyal Bilimler Araştırmaları Dergisi 
Madenlerindeki ihracatın azalmasının sebepleri şu şekilde açıklanmıştır:

"1- Bir kısım amele Frengili Amele Taburu ile Menzil Taburu fertlerinden meydana gelmiş olup, birincisi hastalıklı ikincisi ise amele olarak yetişmemiş olduklarından faydalı olamamaktadir.

2- Amelenin bir kısmı, ister nasihat edilsin isterse ceza verilsin, ocak çavuşu ve başçavuşlarmnn sözlerini dinlememektedir.

3-Ameleler madenlere düzenli bir şekilde gelmemekte, firar etmekte ve bunlarn takibini yapan zabıtalar görevlerini kötüye kullanmaktadır.

4-Amele yevmiyeleri düzenli bir şekilde ödenmemektedir.

5-Ameleye ekmekten başka yiyecek gıda maddesi verilmemesi(BOA, DH.I. UM., E-50/416) sonucu, yeterli beslenemeyen amele verimli çalışamamaktadır.

6-Bazı madenciler, kömürün satış fiyatının düşük olması bahanesiyle, ihracatın artırılmasına gayret göstermemektedir "(BOA, DH.İ. UM., E-50/4-16).

Raporda, ihracatın azalmasının sebepleri tespit edildiği gibi, bu sebeplerin ortadan kaldırılmasına yönelik alınması gereken tedbirler de açıklanmıştır. Söz konusu rapor, Bolu Mutasarrıflığı tarafından 26 Ağustos 1334 (26 A ğustos 1918) tarih ve 47 numaralı yazı ile Harbiye Nezaretine gönderilmiştir(BOA, DH.İ. UM., E-50/4-17/18).

Ereğli Kömür Madenlerinde ihracatın azalması ve bu duruma bir çözüm bulunamaması üzerine konu, Meclis-i Vükelâ tarafından 18 Ağustos 1334 (18 Ağustos 1918) tarihli toplantıda ele alınmış ve görüşme neticesinde özetle;

"Ereğli Havza-i Fahmiyyesi'nde ihracâtın günden güne azalmasından dolayı havza dahilinde kömür ihracâtının tanzîmi için bi'l-fiil yerinde inceleme yaparak alınacak kararların esasların hazırlamak üzere Harbiye, Bahriye, Nafia Nezâretleri ile Ticâret ve Zirâat Nezâretinden katılacak temsilcilerden oluşturulacak bir komisyonun acele olarak teşkîli ve adı geçen yere gönderilmesinin tensip olunduğunun ilgili dairelere tebliği" (BOA, MV., 212/141) kararlaştırılmıştır.

Meclis-i Vükelânın bu kararı doğrultusunda adı geçen nezaretlerin temsilcilerinden oluşturulan komisyon Ereğli Havzası'na gitmiştir(BOA, MV., 212/203). Havzada araştırma ve incelemelerde bulunan komisyon sıkıntıların kaynağ1 olarak havza idaresindeki iki başlılığa ve işletme anlayışındaki yanlışlıklara dikkat çeken bir rapor hazırlamıştır. Bu rapora istinaden Harbiye Nezareti tarafından Ereğli Havzası'nın kontrol ve denetimini Harp Kömür Merkezine bağlanacaktır(BOA, DH.İ. UM., E-50/4-24). 


\section{Osmanlı Devleti'nin I. Dünya Harbi Esnasında Yaşadığı Kömür Sıkıntısı ve Alınan Tedbirler}

\section{I.E. Zonguldak Harp Kömür Komisyonunun Kaldırılması ve Yerine Zonguldak Maden Müdüriyetinin Kurulması Ve Çalışmaları}

Ereğli Havzası'na yönelik düşman saldırılarının sona ermesinden sonra buradan çıkarılan kömür miktarındaki azalmanın iki temel sebebe dayandığı görülmüştür. Bunlardan birincisi, madenlerde çalışacak yeterli sayıda amele istihdamının gerçekleştirilememesidir. İkincisi ise, madencilerden satın alınan kömürlerin bedelleri düzenli bir şekilde ödenmediği için madencilerin malî açıdan sıkıntıya girmeleridir. Ancak, bu konularda çeşitli uyarılar yapılmasına ve bir takım tedbirler alınmasına rağmen başarılı olunamamıştır. Harbiye Nezareti, havzanın mevcut idarî yapısı ve işletme anlayışı ile bu meselelerin çözümlenemeyeceği düşüncesinden hareketle Ereğli Kömür Madenlerinin idaresinin de Harp Kömür Merkezine verilmesini kararlaştırmıştır.

Bu çerçevede Başkumandanlık Erkân-1 Harbiye Reîsi ve Harbiye Nazırı Enver Paşa tarafından Harp Kömür Merkezine bir talimatnâme gönderilmiştir. 27.8.1334 (27 Ağustos 1918) tarihli ve 5123 numaralı talimatnâme özetle şöyledir:

"Kilimli'de bulunan ocaklar dışında(Kilimli'de bulunan ocaklar metruk olduğu gerekçesiyle askeriyece el konularak işletilmeye başlanmıştır. Bundan dolayı, Kilimli'deki ocaklar talimatnâmede istisna edilmiştir. Bk. BOA, BEO, 347932, 348114, 348405 ve 349097) Ereğli Havza-i Fahmiyyesi'nde bulunan diğer maden ocaklarında kömür istihsâlâtının mümkün olduğunca artınlması, muhâsebâtı ve dağıtımlarının düzenli bir şekilde yürütülmesini sağlamak için Harp Kömür Merkezinin yetkileri şunlardır:

1- Harekât hattını tayîn ve tanzîm etmeye yarayan her türlü iktidar Harp Kömür Merkezine devredilecektir. Ad̆ geçen merkez istihsâl edilmiş ve edilecek olan kömürler hakkında bilumum kararları müstakilen almak vazîfesiyle yükümlüdür.

2- İstihsâl olunan her türlü kömürün dağıtımı, resmî ve özel müesseselere göre satışı ve satış fiâtlarının belirlenmesi, Harp Kömür Merkezi tarafindan yapılacaktır.

3- Madenlerin işletilmesi, satış işlemlerinin yürütülmesi ve istihsâl olunan kömürlerin dağıtımı için gereken paralar Harp Kömür Merkezinin emrine düzenli olarak ödenecektir. Bütün malî teşkilât adı geçen merkezin elinde olacaktır. Kesin hesaplar ve muhtemel gelirler her işletme senesi sonunda yapılacaktır. Çeşitli işletme idarelerine Harp Kömür Merkezi tarafindan para verilecek ve adı geçen idareler her ay sonunda bahsedilen merkeze hesap verecektir.

4- Bu programdaki hükümlerin süratli ve tekelden yapılmasın temin etmek üzere ileride amele kabul ve istihdâmı ve yevmiyelerinin ödenmesi, hususî olarak Harp Kömür Merkezinin vazîfelerindendir.

5- Bütün resmî ve özel kuruluşlara verilecek kömürlerin dağıtımı Harp Kömür Merkezince yapılacak ve verilen kömürlerin paraları nakliye ücreti ve diğer masrafları daima peşin olarak ödenecektir. Özel kişi ve kuruluşların kömürü resmî kuruluşlarm kömürü temin

| Gaziosmanpaşa Üniversitesi Sosyal Bilimler Araştırmaları Dergisi 
edildikten sonra verilecektir.

6- Kömür idhâlâtı da hususî olarak ve sadece Harp Kömür Merkezi tarafindan yapılacaktır. Bu kömürlerin de malî işleri ve dağıtılması aşağıda olduğu gibi yapılacaktır.

7- İşletme idarelerinin, kömür satışından ileri gelen varidât-ı sâfiye hesaplarını talebe hakları olacaktır. Harp Kömür Merkezi tarafindan, bütün özel kömür tüketicilerine verilecek kömür fiâtına zam suretiyle, işletme için ihtiyat akçesi olarak ton başına yirmibeş kuruş alınacak ve kömür satışından dolayı adı geçen merkezin başka para talebine hakkı olmayacaktır "(BOA, DH.İ. UM., E-50/4-24).

Söz konusu emirle, Ereğli Havzası'nın kontrol ve denetimini Harp Kömür Merkezine veren Harbiye Nezareti, alınan yeni kararları ayn tarih ve numara ile Dâhiliye Nezaretine bildirmiştir. Harbiye Nezareti tarafından Dâhiliye Nezaretine gönderilen tezkirede ana hatlarıyla şu hususlara yer verilmiştir:

"Osmanlı Devleti'ne gerekli olan kömürlerin Ereğli Havzası'ndan temin edilmesi ve harp gemileri için gerekli olan özel kömürler ile kok ve antrasit kömürlerinden başka Almanya'dan kömür idhâline bir an önce son verilmesi mevcut harbin gereklerindendir. Bunun temini için Ereğli Havza-i Fahmiyyesi'ne ait esaslı bir teşkilât kurmak mecburîdir. Bu doğrultuda Harp Kömür Merkezine gönderilmiş olan 5123 numarah emirnâmeye uyulmalıdır. 30 Kanun-ı Sânî 1334 (30 Ocak 1918) tarihinde oluşturulan Zonguldak Harp Kömür Komisyonu kaldırılmıştır. 19.3.1334 (19 Mart 1918) tarih ve 1299 numaralı emirle kurulan Maâdin-i Askerî Komiserliği görevine devam edecektir. Adı geçen emirnâmede belirtilen görevler eskiden olduğu gibi komiserlik tarafindan yürütülecektir. Amelelerin iâş̧esinden Levâzımât-ı Umûmîye Dairesi sorumludur. Amelelerin muhtelif madenlere dağıtılması ve ücret işleri bundan sonra Zonguldak Maden Müdüriyetince yapılacaktır. Maâdin-i Askerî Komiserliği eskisi gibi amelelerin iskânın temin edecektir. Ticâret ve Zirâat Nezâretinin Ereğli Havzası'na görevlendirdiği temsilcisi her hususta müstakildir. Zonguldak Maden Müdüriyeti, adı geçen temsilci ile teşrîk-i mesâ̂̂ yapacaktır. Ticâret ve Zirâat Nezâretinin temsilcisi ile Zonguldak Maden Müdüriyeti arasında bir anlaşmazlık çıkar ve uzlaşamazlarsa Harbiye Nezâreti, Ticâret ve Zirâat Nezâreti ile aralarında anlaşacaktır. Şimdiye kadar Harp Kömürü Komisyonunda üyelik yapan Harbiye Nezâreti ile Karargâh-ı Umûmînin temsilcileri bundan sonra Zonguldak Maden Müdüriyetine tayîn edilecektir"(BOA, DH.İ. UM., E-50/4-24).

Harp Kömür Merkezi, Harbiye Nezaretinin talimatı ile kendisine tanınan yetki çerçevesinde, Ereğli Kömür Havzası'ndaki madencilere yönelik bir muhtıra hazırlamıştır. Hazırlanan muhtıra, Karargâh-1 Umumî tarafından madencilere tebliğ edilmiştir. Buna göre; kömürün şekli, istihsal miktarı ile dağıtımı ve satışı hususlarında bütün kararlar Harp Kömür Merkezi tarafından alınacaktı(BOA, MV., 212/203).

Görüldüğü üzere, Harbiye Nezareti, Ereğli Havzası'ndaki Ticaret ve Ziraat Nezaretine bağlı olarak görev yapan Ereğli Madeni Müdürlüğünün her hususta 


\section{Osmanlı Devleti'nin I. Dünya Harbi Esnasında Yaşadığı Kömür Sıkıntısı ve Alınan Tedbirler}

bağımsız olduğunu belirtmiş ve lağvedilen Zonguldak Harp Kömür Komisyonu üyelerinin atanacakları Zonguldak Maden Müdüriyeti ile Ereğli Madeni Müdürü'nün ortak çalışmasını istemiştir. Diğer taraftan Harbiye Nezaretinin talimatıyla Ereğli Havzası ile ilgili bütün kararların Harp Kömür Merkezi tarafından verileceği bildirilmiştir(BOA, DH.İ. UM., E-50/4-24). Dolayısıyla her ne kadar Harbiye Nezareti, Ticaret ve Ziraat Nezaretinin havzadaki idarî yapısına dokunmamış ve onu serbest bırakmış görünse de, Harp Kömür Merkezine verilen yetki ve sorumluluk sebebiyle Ereğli Kömür Madenlerinin idaresini kendine bağlamıştır. Ancak, Harbiye Nezaretinin havza üzerindeki denetimi ele aldığ 1 bu dönemde, havzadaki problemler giderilememiş ve istihsal artırılamamıştır Harbiye Nezareti tarafından Dâhiliye Nezareti'ne gönderilen 4 Eylül 1334 (4 Eylül 1918) tarihli ve 5272 numaralı tezkirede özetle; "Ereğli Havzası'ndaki kömür istihsâlâtının azalması sebebiyle bir takım tedbirler alınmıştır. Bu tedbirlerin başarılı bir şekilde uygulanabilmesi için ilgili nezâretler ve bütün resmî makamlarn yardımcı olmaları gerekmektedir. Bu tedbirlerden birincisi amelenin havzaya getirtilmesidir. Bunun için bölgedeki ilgili makamlara nezâretinizce gerekli emirlerin verilmesi rica olunur. Amelelerin iâşelerinin yetersiz olduğu ve ücretlerinin bilhassa Ereğli Şirketi tarafindan ödenmediği bilinmektedir. Fakat alınan etkili tedbirler ile bu gibi kötü durumlarn ortadan kalkacağı ümit edilmektedir. Amelenin iskân şartlarnnın iyileştirilmesi ve bundan başka kışlık elbise verilmesi için de gerekli tedbirler alınmıştır. Bu hususta nezâretinizin de yardımlan istirhâm olunur" denilmektedir(Bk. BOA, DH.I. UM., E-50/4-21). Harbiye Nezareti tarafından bazı tedbirler alınmakla beraber amele meselesi çözümlenememiştir. Bunun üzerine Maâdin-i Askerî Komiser Vekili Kaymakam Osman Cevdet tarafından Karargâh-1 Umûmî Riyâset-i Sânîyesine yazılan 23.9.1334 (23 Eylül 1918) tarih ve 11 numaralı tezkirede özetle şu husus dile getirilmiştir: "Amelenin önemli bir kısmı Devrek kazasından oldŭ̆u halde kaza kaymakamı ile Çaycuma Nahiyesi Müdürü tarafindan, muaşşir, ihtiyar heyeti, muhtar, korucu diye ayrilmakta ve bunlarn madenlere gitmesi engellenmektedir. Hatta gönderilen askerî birlikler tarafindan karakola götürülenler de serbest bırakılmaktadır. Bu sebeple madencilerin bu gibi bahanelerle madenlere sevkine engel olan hususlarn ortadan kaldırılması için Devrek, Zonguldak, Ereğli ve Bartın kaymakamlarına gerekli emirlerin verilerek görevlerini yerine getirmeleri sağlanmalıdır". Karargâh-1 Umumî Riyâset-i Sânîyesi tarafından 4 Teşrîn-i Evvel 1334 (4 Ekim 1918) tarih ve 12623/22709 numaralı yazı ile durum Dâhiliye Nezaretine bildirilmiştir. Bunun üzerine Dâhiliye Nezaretince, Harbiye Nezaretinin yazısı doğrultusunda gereğinin yapılması 10 Teşrîn-i Evvel 1334 (10 Ekim 1918) tarihinde Bolu Mutasarrıflığına tebliğ edilmiştir(BOA, DH.İ. UM., E50/4/6-7-8-9-10). Zaten, bir süre sonra Harp Kömür Merkezi Ticaret ve Ziraat Nezaretine bağlanacaktır.

\section{I.F. Harp Kömür Merkezi'nin Ticaret ve Ziraat Nezareti'ne Bağlanması}

Daha önce kömür ihracatının düzenlenmesi amacıyla yerinde inceleme yapmak üzere Harbiye, Bahriye, Nafia ile Ticaret ve Ziraat Nezaretlerinden katılacak kişilerden

| Gaziosmanpaşa Üniversitesi Sosyal Bilimler Araştırmaları Dergisi 
bir komisyon oluşturulmuş ve Ereğli Havzası'na gönderilmişti. Komisyon burada yaptığ1 incelemeler sonucunda, Ereğli Kömür Madenlerinden en iyi şekilde istifade edilebilmesi için alınması gereken tedbirleri tespit etmiş ve aldığı kararları bir mazbatayla Ticaret ve Ziraat Nezaretine bildirmiştir. Ticaret ve Ziraat Nezareti, bu mazbatayı kendi düşünce ve tekliflerinin yer aldığı 28 Eylül 1334 (28 Eylül 1918) tarihli tezkire ile birlikte, Meclis-i Vükelâya göndermiştir. Ticaret ve Ziraat Nezaretinin tezkiresindeki düşünce ve teklifler şu şekildedir;

"Harp Kömür Merkezinin vazîfe ve selâhiyeti hakkında Harbiye Nezâretinden çıarılan talimatnâme ile Karargâh-ı Umûmîden madencilere tebliğ edilen muhtırada kömürün şekli, istihsâl miktarı ve tevzî ve satışı hususlarında bi'l-cümle kararların Harp Kömür Merkezi tarafindan kendi nokta-i nazarına göre ittihâz edileceği beyân edilmiştir. Bu durum ahkâm-ı mevzua ile gayr-i kâbil-i telif görünmüş olduğundan bahisle, kömür istihsâlâtına nezâret keyfiyeti maden muamelâtından doğrudan doğruya mesul bulunan maden idaresine tevdî edilmelidir. Amelenin celb ve cemî ve iâşesi hususunda salim bir usûl takibi ile maden ashabının da bu konuyla alakadar olması ve miktar-ı istihsâlâtdan mesûl tutulmaları gerekmektedir. Madencilere lüzumu olan mevâdın tedâriki emrinde hükümetçe de yardımcı olunması elzemdir"(BOA, MV., 212/203).

Konu, 25 Z 1336 (2 Ekim 1918) tarihinde Meclis-i Vükelâda görüşülmüş ve şu kararlar alınmıştır: "Mütâlaât ve teklifât-ı mesrûde meclisce kabul olunarak Harp Kömür Merkezinin Ticâret ve Zirâat Nezâretine bağhl olması bi't-tensib bu babda îcâb eden kanun, nizamnâme ve talimatnâme layihalarnmın tanzîmi hususunun Ticâret ve Zirâat Nezâretine cevaben ve Harbiye Nezâretine resen izbârı kararlaştırıldı"(BOA, MV., 212/203).

Meclis-i Vükelâ tarafından onaylanan Ereğli Kömür Madenlerine ait kararlar Ticaret ve Ziraat Nezareti tarafından 7 Teşrin-i Evvel 1334 (7 Ekim 1918) tarihinde on bir madde halinde düzenlenerek neşredilmiştir. Bu kararlar ile havzadaki kömür üretiminin artırılması için gerekli düzenlemeler yapılmıştır (BOA, DH.İ. UM., E-50/413-1/2).

Meclis-i Vükelâda hazırlanan kararnâme ile Ereğli Kömür Madenleri konusunda Harbiye Nezareti devre dişı bırakılmıştır. Böylece, adı geçen madenlerin idaresi tamamen Ticaret ve Ziraat Nezaretine geçmiştir. Ticaret ve Ziraat Nezaretince neşredilen kararlar havza üzerinde olumlu bir etki yapmıştır. Bundan dolayı havzada belli bir düzen sağlandığı gibi kömür ihracatında da artış olmuştur. Havzadaki düzenin sağlanması ve ihracatın artmasında, madencilerin çıkardıkları kömürün /\%40'ının satışına izin verilmesi kararı etkili olmuştur. Zira madenciler serbestçe sattıkları kömür bedeli ile belli ölçüde de olsa malî açıdan durumlarını düzeltme imkânına sahip olmuşlardır. Bunun sonucunda istihdam ettikleri memur ve işçilerin ücretlerini ödeyebilme imkânına kavuşmuşlardır. Dolayısıyla bu durum amele sıkıntısının giderilmesinde etkili olmuştur. Ayrıca amelenin istihdamı sorumluluğu ile 


\section{Osmanlı Devleti'nin I. Dünya Harbi Esnasında Yaşadığı Kömür Sıkıntısı ve Alınan Tedbirler}

yapılacak malzeme vb. yardımların karşılığında, madencilerin belli bir miktar kömür ihracından mesul olmaları da istihsalin artmasında etkili olmuştur. Fakat bu durum sürekli olmayacak, mütareke dönemi ve buna bağlı gelişmelere paralel olarak havzadaki kömür üretimi ve kömürlerin havzadan naklinde sıkıntılar yaşanmaya devam edecektir(Mütareke dönemi kömür sıkıntısı için bk. Çavdar,2014:95-125)

Kömür üretimi ve taşınmasındaki problemler sebebiyle vapur, tren, değirmen, fabrika ve elektrik aydınlatması gibi kömüre ihtiyaç olan her yerde ciddi sıkıntılar ortaya çıkmıştır. Mesela; vapur, tren ve tramvaylar düzenli bir şekilde işletilememiş ve ulaşım vasıtalarına aşırı derecede zamlar yapılması sebebiyle ulaşımda sıkıntı oluşturmuş(Çavdar,2014:116), su pompaları düzenli çalıştırılamadığından büyük ölçüde su sıkıntısı olmuş bu yüzden uzun süreli su kesintileri yapılmış ve sokaklar temizlenemediğinden pislik içerisinde kalmış ve su fiyatları artmıştır(Çavdar,2014:114), yine yeterince elektrik üretilemediğinden elektrik kesintileri yaşanmış ve insanlar karanlıkta geceleri sokağa çıkamayacak duruma gelmişlerdir(Çavdar,2014:122). Şüphesiz harp içerisinde bulunan bir ülkede başta askeri üretim olmak üzere bilumum levazım ve iaşe işleri ve nakilleri konusunda ciddi sıkıntılar yaşandığı ve bunun da harbin gidişatı üzerinde olumsuz etkiler doğuracağı bilinen bir gerçektir.

\section{SONUÇ}

Osmanlı Devleti I. Dünya Harbi esnasında kendine yetecek kömür yatakları ve ocaklarına sahip olmasına rağmen çok ciddi ölçüde kömür sıkıntısı çekmiştir. Harbin getirdiği sıkıntılar yanında en önemli kömür üretim merkezi olan Ereğli Havzası ve buradan yapılan nakliyatın Rus saldırılarından korunamaması sıkıntının ana sebebini oluşturmuştur. Havzadan çıkarılan kömürlerin nakli hususunda deniz yolu dişında karayolu ve demiryolu gibi farklı yoların yapılmamış olması da önemli bir eksiklik olarak görülmüştür. Ayrıca tecrübeli ve deneyimli madencilerin cephelere gönderilmesi, kömür bedellerinin devlet tarafından zamanında ödenememesi havza üretiminin azalmasında etkili olmuş ve sahip olunan kaynaklardan yeterince yararlanılamamıştır. Havza kaynaklarından yeterince istifade edilemediği için başta İstanbul olmak üzere ülkenin önemli yerleşim yerlerinde su, ısınma, aydınlatma ve ulaşım konularında sıkıntı yaşanmıştır. Ayrıca harp sanayi üretimi ve nakliyatı da bu durumdan olumsuz etkilenmiş ve savaşın seyrine etki etmiştir.

\section{KAYNAKLAR}

Arşiv Kaynakları

a)Başbakanlık Osmanlı Arşivi: BEO, 244149, 347932, 348114, 348405 ve 349097, DH.İ. UM., 19-1/1-10-21, DH-İ. UM., 89-2/1-26, DH-İ. UM., E-26/57, DH.İ. UM., E-50/4-23, DH- EUM. EMN, 90/58, DH, ŞFR.,

| Gaziosmanpaşa Üniversitesi Sosyal Bilimler Araştırmaları Dergisi 
43/ 194, DH. ŞFR., 46/145-159, DH.ŞFR., 54/241, İ. Hus, 1325 N/82, İ.Meclis-i Mahsûs,1333

B/18, MV, 213/72, MV., 200/60, MV., 207/76, MV., 212/141-203,

b)Genelkurmay Başkanlığı ATASE Arşivi:

Gazeteler

ATASE, BDH, Kls;903, Kls., 904, Kls., 2631,

Takvîm-i Vekayî, 2264

\section{Kitaplar, Tezler, Bildiriler, Makaleler}

Besbelli, S.(1976), Birinci Dünya Harbinde Türk Harbi, Deniz Harekatı, 8, Ankara:ATASE Yayını Çatma, E.(1998), Asker İşçiler, İstanbul:Ceylan Yayıncılık

Çavdar,N.(2014), 'Birinci Dünya HarbiSonunda İstanbul'da Kömür Kıtlı̆̆ı ve Buna Bağl1 Sıkıntılara Çözüm Arayışları", Atatürk Araştırma Merkezi Dergisi,89, s.95-125

Dölen, E.(2014), "Osmanlı Döneminde Kocaeli'ndeki Sanayi Kuruluşları", Kocaeli Tarihi Sempozyumu(2-4 Mayıs 2014) Bildirileri, Kocaeli, s.670-685

Eldem, V.(1994), Osmanlı İmparatorluğunun İktisadî Şartları Hakkında Bir Tetkik, Ankara: Türk Tarih Kurumu Yayını

Eldem, V.(1994), Harp ve Mütareke Yıllarında Osmanlı İmparatorluğunun Ekonomisi, Ankara: Türk Tarih Kurumu Yayını

Genç, H.(2007), "Ereğli Kömür Madenleri", Marmara Üniversitesi Sosyal Bilimler Enstitüsü Doktora Tezi, İstanbul

Kara, M.(2009), ‘Ereğli Kömür Havzası ve Cumhuriyet Dönemi Şekillenişi”, Abant İzzet Baysal Üniversitesi Sosyal Bilimler Enstitüsü Yüksek Lisans Tezi, Bolu

Kara, M.(2010), Son Mükellefler Ereğli Kömür Havzası'nda Zorunlu Çalıştırma(1940-1947), İstanbul: Ares Yayınları

Kara, M.(2013), “Osmanlı Devleti'nin Son Döneminde Ereğli Kömür Havzası(1829-1920)", History Studies, Volume 5, Issue 1,s.223-249

Naim, A.(1934), Zonguldak Havzası,Uzun Mehmetten Bugüne Kadar, İstanbul: Hüsnütabiat Matbaas1

Öğreten, A.(2006),'Ereğli Kömür Madeni Havzasında İlk Üretim", Atatürk Üniversitesi Türkiyat Araştırmaları Enstitüsü Dergisi, 31, s.135-160

Sarıkoyuncu,Ali.(1992), Milli Mücadelede Zonguldak ve Havalisi, Ankara:Türk Tarih Kurumu Yayını

Şirket-i Hayriye İdaresi,(1337), Harb-i Umumi ve Şirket-i Hayriye 1330-1334,İstanbul: Bahriye Matbaasi

Tak, İ.(2001), "Osmanlı Döneminde Ereğli Kömür Madenleri”, Atatürk Üniversitesi Sosyal Bilimler Enstitüsü Doktora Tezi, Erzurum

Yorulmaz, Ş.(1998), "Türkiye' de Kömürün Keşfi ve Kömür İşletme İmtiyazları(1829-1937)", Türkiye 11. Kömür Kongresi Bildiriler Kitabı, Ankara: Kozan Ofset . 